\title{
Identification of Internet Addiction of Online Gamers and Non-gamers in Jakarta Internet Cafés Through the Hybrid of Ethnographic Approach and Genetic Algorithm Method
}

\section{Devie Rahmawati ${ }^{1}$ and Yulius Eka Agung Seputra²}

${ }^{1}$ Communication Studies, Vocational Program, Universitas Indonesia, Depok, Indonesia

${ }^{2}$ Vocational Program, Universitas Indonesia, Depok, Indonesia

\section{Abstract}

The aims of this Hybrid approach are to analyse and predict types of internet users in Indonesia. This study uses online-based participant observation method to collect its primary data and then proceed to assess it with the genetic algorithm analysis

Corresponding Author: Devie Rahmawati deviers@vokasi.ui.ac.id

Received: 8 June 2018 Accepted: 17 July 2018 Published: 8 August 2018

Publishing services provided by Knowledge E

(c) Devie Rahmawati and Yulius Eka Agung Seputra. This article is distributed under the terms of the Creative Commons

Attribution License, which permits unrestricted use and redistribution provided that the original author and source are credited.

Selection and Peer-review under the responsibility of the 2 nd ICVHE Conference Committee.

\section{S OPEN ACCESS}

method. The data of ethnographic approach was analysed using thematic analysis. Findings were corroborated by the algorithm analysis. Through the combination of Ethnographic approach and Genetic Algorithm analysis, the results of this study show that internet addiction significantly influences by the types of internet users.

Keywords: Genetic Algorithm, Ethnographic, internet-based analysis

\section{Introduction}

Internet Addiction had become a phenomenon in modern society, whereby online games and other forms of entertainment can be accessed easily on the internet. Currently, type of internet users diverse; ranging from adults, teenagers, to underage children-all can easily interact and connected by the online network [1].

The potency of internet addiction immensely facilitated by the development of smartphones with access to the internet. This technology development induces people's interests toward gadgets; in which context allow them to conveniently access online games and other forms of online entertainments-including social media, blog, and streaming website. The Internet itself, according to some works of literature, has the potential to create a 'flow experience' for their users [2].

Therefore, it is reasonable that online activity-such as gaming-can induce the users to surf for an extensive amount of time and even neglected their other activities. The 
concept of internet addiction in this research identifies as 'when online activities had overwhelmed the user and caused problems in the user's social live' [3]. This identification is based on the criteria from Diagnostic and Statistical Manual of Mental Disorder$\mathrm{V}(\mathrm{DSM}-\mathrm{V})$ that generally utilised by psychologist and psychiatrist in diagnosing the symptoms of addiction. Nevertheless, the term of 'video game addiction' is rarely studied by scholars and most of its argumentations are solely based on public hysteria [4].

The urge to provides new perspectives regarding internet addiction had encouraged this study to conduct interpretive ethnography approach, which emphasise the efforts to examine internet user's attachment to online entertainments from the user's own perspective. Findings in this research then used as the foreground for genetic algorithm formulation for data analysis, where the algorithm is expected to project the potency of internet addiction-both in online gamers and non-gamers.

The advantage of interpretive ethnography approach lies in its capability of presenting a systemic representative on how the subjects conduct, experience, and develop their social interaction. The utmost important factor of this approach is that behaviour of this study's subjects is not assessed externally by researchers; but instead, it is interpreted internally by each subject based on their online activities [5].

Until recently, various scholarly works on internet addiction conducted using existing theories as their guideline. Hence, to date, efforts to schematise the pattern of internet addiction were not directly abstracted from subjects' perspective but generated from the third person's perspective (the observers). Through ethnographic approach, researchers of this study will produce concepts, categories, patterns, and models that reflecting subject's experience, feeling, and thought. As the result, findings of this study are purely subtracted from primary data and not based on any existing scholarly literature [6].

On the other hand, the genetic algorithm method effectively supports this study to convert and systemise ethnographic data into a statistical model of computing, which later supports the analysis and research findings formulation. Genetics algorithm method of soft computing imitates ways the human brain works; hence it can be used to analyse several variables that affect subjects' addiction to the internet. Basically, this method can be used to identified and analysis multiple plausible causes for numerous subjects (multi-collinearity) [7]. 
To summarise, this research aims to investigate internet addiction level on online gamers and other internet users, by utilising genetics algorithm to analyse ethnographic data.

\section{Literature Review}

\subsection{Internet addiction}

Internet addiction is a condition where an individual is unable to control their desire to access the internet. The addiction can appear in form of attachments to social media, e-mail, pornography, online gamble, online game, chatting, and other activities that related to the internet [8].

Internet addiction in all forms had become a distinct phenomenon in modern society. Presently, game online and other online entertainments can easily be accessed following the rapid development of the internet. In accordance to the internet's increasing popularity, its users' category also broadens, covering a various range of ages.

The invention of smartphones greatly contributed on the deeper infiltration of communication and technology in modern society's life. Different with the computer that has limited mobilisation, a portable device such as smartphone facilitates its users to connect to the internet in almost anywhere. This advantage allows the internet users to access online games and other of entertainments without the need to arrange a specific time and particular place for their activities. This circumstance increases the possibility of users' immersion-through flow experience-into the internet.

The stimuli from online games, particularly, encourages its players to feel intrigued and challenged. Online games present a higher degree of difficulties from one to the next level of the game; generating curiosity for its players to pass along after completing a particular mission or quest. The increasing difficulty of game's levels often accompanied by provisions of rewards in form of new items, credits, or skills for the next mission. Additionally, each level of the game usually presented a new challenge, obstacle, field, and even tools to attract players' attachment [9].

With such immersive experiences, it is evident that online games can lead its players to immerse and continuously play the game-in some cases, the game even caused them to neglect their other activities. By the time online gamers had completely obsessed with a particular game, had difficulties in controlling their time or desire to play, and ignoring their social life; researchers of this study are able to identify their condition as online gaming addiction [10]. This identification is known as Diagnostic 
and Statistical Manual of Mental Disorder-V (DSM-V), which usually used to diagnose a person that indicated with online game addiction [11].

Prior studies on computers, online games, and internet addiction, for example, argues that high level of engagement on games often lead its players to experience some psycho-social problems without showing any signs of addiction. Therefore, not all online gamers can be categorised as addicts even though their attachment to games caused a disturbance in their psycho-social state. This proves that as a form of entertainment, moderate usage of online game is actually harmless [12].

Other studies on online game addiction aim to identify players' motivation in online gaming [13-19]; investigate supporting factors that caused online game addiction [20, 21,22-26]; explore the way to prevent, respond and cure online game addicts [27-32]; identify biological and medical symptoms that shown by addicts [33-37]; as well as to develop an instrument to measure when an online gamer can be categorised as an addict [38-43].

Nevertheless, until today, understanding online game addiction from the firstperson perspective has not been done in any research although it poses a great importance for this study. This type of research can contribute to project the development of game online addiction potencies in the future.

\subsection{Ethnography}

For this type of research, interpretive ethnography considered as one of the most suitable approaches to identify the dynamics of internet addiction based on the participants' perspective. Ethnography is a form empirical research that observes one particular phenomenon in its 'natural' setting [44].

In its implementation, ethnographic research heavily relies on participant observation method. Through ethnographic, researchers are expected to understand the phenomenon of online game addiction from the first-hand players. Additionally, this type of research allows the online game addiction issue to be seen as a social phenomenon, rather than a mere psychology problem [45].

\subsection{Discriminant analysts}

Discriminant analysis is a variant of the statistical method that generally used to create a classification. The model of discriminant analysis consists from series of tests, such 
as multicollinearity test, data distribution, normal multivariate, similarity in variancecovariance matrix, as well as finding differences between data mean. If the correlations between variables are more than 0.8 , then the case can be identified as a multicollinearity [46].

The genetics algorithm allows recurrence in the data to acquire the global optimum value. There are six steps in genetics algorithm:

1. Forming a base population which consisted from 100 chromosomes. The type of chromosome in this step is bitstring to support the variable selection process.

2. Evaluating each chromosome based on its fitness value.

3. Selecting parents to be duplicated by using roulette wheel selection.

4. Conducting the cross-linking process.

5. Conducting the mutation process.

6. Repeating step 1-6 if the optimum chromosome-that became the solution of the problem-is not yet obtained.

This ethnographic study, which conducted in 1,5-year timespan-from January 2015 to June 2016-found that there are 150 online gamers among 175 internet café users in Jakarta. On the other hand, 25 other users' activities are identified as checking and sending email, accessing social media, searching for online news, as well as simply surfing the internet websites.

From the data, 143 of the online gamers are male. Most of the male gamers have the chance to be in internet café for hours due to their parents' traditional belief, where 'boys are supposed to be outside their home more than they are inside.' Boys in Jakarta are given a high tolerance for their aggressive and challenging behaviours; in contrary with girls that considered to be weak, helpless, and prone to face troubles if let to be outside for a long time. It can be seen from the testimony of the informants:

\section{Informant I}

'I am a boy. I was told that I shouldn't stay home for too long. My father said that I should be more like him, going out often.' 


\section{Informant II}

'I am allowed to come home late. I am a boy. Nor my mother or my father never asked me questions [on why I come home late]. It is different for the girls, they have it quite difficult [to get parent's permission].'

Most of these online gamers are underage children, teenagers, and young adults between 9 to 24 years old. Gamers of this age range generally do not have any other important priority that urged them to put a better use of their time. Additionally, in the perspective of family and society, it is considered to be normal for people in this age range to play games in internet café.

\section{Informant III}

'I often play a game in my phone at home. So [actually] I don't mind if I don't go to an internet café. However, after school, I usually have a lot of spare time. Therefore, I prefer to go to an internet café. I can also play at home, but it is less fun since I cannot play with my friends.'

\section{Informant IV}

'Might as well, as long as I am still in school. I only have to eat, study, play and do not have to think about money. It is better to play [online games]. Better than being a delinquent.'

Based on their statement, there are several factors that support them to play online games in internet café:

1. The availability of economic resources to play games. This factor gives gamers the opportunity to cover all their needs and necessity in the internet café. Their needs usually consisted of paying the internet bill, buying foods, and purchasing cigarettes in the café.

2. Parents' permission for the online gamers is based on several aspects:

(a) The stability of their children's achievement level at school, university, or office;

(b) Their children can be avoided from the negative impact of students' fight (towuran), drugs, and free sex; 
(c) Parents' busy activity led the internet café to be the 'best day care' for their children since it is relatively safe and affordable;

(d) In several cases, by playing online games, their children can provide themselves economically;

(e) Internet café waiters are willing to take care of their children as long as they pay the bills.

\section{Informant V}

'I can prove that I can be promoted to the next grade with satisfactory results. That is why my mother still trusts me and even give me the money to go to the internet café. It is all because my results are okay.'

\section{Informant VI}

My parents always warn me to avoid fighting, drugs and impregnate a girl. I told them that I only go to the internet café, they still can monitor me since I've done nothing wrong. [The worst I can do is] maybe smoking. Basically, my parents are content that I only playing games instead of conducting any mischievous act. This is why my parents give me extra money.'

\section{Informant VII}

'I rarely meet with my parents. Well, they are so busy. They don't even know what I am doing. Every time they call me, and I told them that I am at the neighbourhood internet café, they instantly feel safe. In the end, they always give me extra money to go to the internet café.'

\section{Informant VIII}

'Well, I can be in a bad mood if I am not playing games within the day. Therefore, in front of my parents, I always behave nicely to get their permission [to play online games]. I never swear, or show any bad manners [in front of my parents].' 


\section{Informant IX}

'Even though I rarely lie [about playing online game to my parents], I have to force myself to stop playing games in the exam week. So, my marks can be good. If I get bad marks, they will not allow me to play [online games] anymore.'

In this ethnographic findings, there are patterns that induce online game addiction in internet users, namely sex, financial allowance, age range, and parenting style.

\section{References}

[1] Widyanto, L.; Griffiths, M., "'Internet Addiction': A Critical Review". International Journal of Mental Health and Addiction. Springer Science,2006

[2] Liu, Chuang-Chun., I-Cheng Chang. (2016). Model of online game addiction: the role of computer-mediated communication motives. Telematics and Informatics. Vol 33, hlm 904-915

[3] Griffiths, International Journal of Mental Health and Addiction2010

[4] Wood, Richard T.A. (2008). Problems with the concept of video game "addiction": some case study examples. Int J Ment Health Addiction. Vol 6, hlm 169-178

[5] Brewer, John D. (2000). Ethnography. Berkshire: Open University Press.

[6] Mulyana, Deddy., Solatun. (2008). Metode Penelitian Kualitatif. Contoh-contoh penelitian kualitatif dengan Pendekatan Praktis. Bandung : Remaja Rosdakarya

[7] Chiang L. H., and Pell R. J, "Genetic Algorithms Combined with Discriminant Analysis for Key Variable Identification", Journal of Process Control 14, 143-155 (2004).

[8] Chennakesava Reddy A and Sundararajan S," Influences of ageing, inclusions and voids on the ductile fracture mechanism of commercial Al-alloys", J. Bull. Material Sci. 28(1), 101-105,2005

[9] Charlton, J.P., I.D.W Danforth. (2006). Distinguishing addiction and high engagement in the context of online game playing. Computers in Human Behavior, article in press

[10] Gentile, D. (2009). Pathological Video- Game Use Among Youth Ages 8 to 18: A National Study. Psychological Science, 20(5), 594-602. Retrieved from http://www. jstor.org/stable/40575069

[11] Lemos, Igor Lins., Adriana Cardoso., Everton Botelho Sougey. (2016). Validity and realibility assessment of the brazilian version of the game addiction scale (GAS). Comprehensive Psychiatry. Vol 67, hlm 19-25 
[12] Weng, Chuan-Bo., Ruo-Bing Qian., Xian-Ming Fu., et al. (2013). Gray Matter and White Matter abnormalities in online game addiction. European Journal of Radiology. Vol 82, hlm 1308-1312

[13] Grüsser, S. M., R. Thalemann dan M. D. Griffiths. (2005). "Excessive computer game playing: evidence for addiction and aggression?" dalam Cyberpsychology \& Behovior, 10:290-292.

[14] Sammis, Jeffery. (2008). Video game addiction \& depression rates among online video game players. Wright Institute

[15] Oggins, Jean., Jeffrey Sammis. (2012). Notions of Video Game Addiction and Their Relation to Self-Reported Addiction Among Players of World of Warcraft. Int J Ment Health Addiction. Vol 10, hlm210-230

[16] Kuss, D. J. (2013). Internet gaming addiction: current perspectives. Psychology Research and Behavior Management, 6, 125-137. http://doi.org/10.2147/PRBM. S39476

[17] Kowert, Rachel. (2015). Video Games and Social Competence. Routledge Advances in Game Studies. Taylor \& Francis.

[18] Hussain, Zaheer., Glenn A. Williams., Mark D. Griffiths. (2015). An exploratory study of the association between online gaming addiction and enjoyment motivations for playing massively multiplayer online role-playing games. Computers in Human Behavior. Vol 50, hlm 221-230

[19] Chen, Chen., Louis Leung. (2015). Are you addicted to candy crush saga? An exploratory study linking psychological factors to mobile social game addiction. Telematics and Informatics

[20] Park, Yangil., Jeng-Chung V. Chen. (2007). In search of factors to online game addiction and its implications. Journal of International Technology and Information Management. Vol 16

[21] Langley, Alex B.S. (2010). Correlates of video game addiction. University of North Texas.

[22] Keser, Hafize., Necmi Esgi. (2012). An analysis of self-perceptions of elementary school students in terms of computer game addiction. Procedia-Social and Behavioral Sciences. Vol 46, hlm 247-251

[23] McBroom, Evan S.(2013). An examination of correlates of video game and internet addiction. University of Toledo

[24] Sul, Sooyoung. (2015). "Determinants of Internet Game Addiction and Therapeutic Role of Family Leisure Participation," dalam Phenom Macrocycl Chem. 82:271-278. 
[25] Toker, Sacip., Meltem Huri Baturay. (2016). Antecedents and consequences of game addiction. Computers and Human Behavior. Vol 55, hlm 668-679

[26] Loton, Daniel., Erika Borkoles., Dan Lubman., Remco Polman. (2015). Video Game Addiction, Engagement and Symptoms of Stress, Depression and Anxiety: The Mediating Role of Coping. Int J Ment Health Addiction

[27] Xu, Z., Turel, O., \& Yuan, Y. (2012). Online game addiction among adolescents: Motivation and prevention factors. European Journal of Information Systems,21(3), 321-340.doi:http://dx.doi.org/10.1057/ejis.2011.56

[28] Han, Doug Hyun.,In Kyoon Lyoo., Perry F. Renshaw. (2012). Differential regional gray matter volumes in patients with on-line game addiction and professional gamers. Journal of Psychiatric Research. Vol 46, hlm 507-515

[29] Vaisman, Zohar. (2012). A cognitive-behavioral therapy model for the tratment of online video game addiction. University of Chicago

[30] Jager, Susanne., Kai W Müller., Christian Ruckes., Tobias Wittig., et al. (2012). Effects of a manualized short-term treatment of internet and computer game addiction (STICA): study protocol for a randomized controlled trial. Jäger et al. Vol 13, hlm 43

[31] Graham, Joseph M. Jr. (2014). Narrative therapy for treating video game addiction. Int J Ment Health Addiction. Vol 12. hlm 701-707

[32] Yu, Jin-Hui.,Tai-Young Park. (2016). Family therapy for an adult child experiencing bullying and game addiction: an application of bowenianand MRI theories. Contemp Fam Ther

[33] Ream, Geoffrey L., Luther C. Elliot., Elloise Dunlap. (2011). Playing video games while using or feeling the effects of substances: associations with substance use problems. Public Health. Vol G keepers. (1990). A phatological preoccupation with video games. Journal of the American Academy of Child and Adolescent Psychiatry. Vol. 29 (1), hlm 49-50

[34] Weng, Chuan-Bo., Ruo-Bing Qian., Xian-Ming Fu., et al. (2013). Gray Matter and White Matter abnormalities in online game addiction. European Journal of Radiology. Vol 82, hlm 1308-1312

[35] Hyun, Gi Jung., Goug Hyun Han., Young Sik Lee., Kyoung Doo Kang., et al. (2015). Risk factors associated with online game addiction: a hierarchical model. Computers in Human Behavior. Vol 48, hlm 706-713

[36] Han, Doug Hyun.,In Kyoon Lyoo., Perry F. Renshaw. (2012). Differential regional gray matter volumes in patients with on-line game addiction and professional gamers. Journal of Psychiatric Research. Vol 46, hlm 507-515 
[37] Shive, Ivy. (2015). Self and environmental exposures to drinking, smoking, gambling or video game addiction are associated with adult hypertension, heart and cerebrovascular diseases, allergy, self-rated health and happiness: japanese general social survey, 2010. International Journal of Cardiology. Vol 181, hlm 403412

[38] Cheung, L.M., \& Wong, W.S. (2011). The Effects of Insomnia and Internet Addiction on depression in Hongkong Chinese adolescents. An Explanatory Cross-sectional analysis. Journal of Sleep Research, 20(2), 311-317.

[39] Jap, T., Tiatri, S., Jaya, E. S., \& Suteja, M. S. (2013). The development of Indonesian online game addiction questionnaire. PLoS One, 8(4) doi:http://dx.doi.org/10.1371/ journal.pone.0061098Kim, Eun Joo., Kee Namkoong., Taeyun Ku., Se Joo Kim. (2008). The relationship between online game addictionand aggression, self-control and narcisstic personality traits. European Psychiatry. Vol 23, hlm 212-218

[40] Lee, Zach W.Y., Christy M.K. Cheung., Tommy K.H. Chan. (2015). Massively multiplayer online game addiction : instrument development and validation. Information \& Management. Vol 52, hlm 413-430

[41] Petry, M. Nancy., Charles, O.Brien. (2013). Internet gaming disorder adn the DSM 5. Society for The Study of Addiction. Vol. 108, Issue 7 hlm. 1186-1187

[42] Gaetan, S., A. Bonnet, V. Brejard, F. Cury. (2014). French validation of the 7-item game addiction scale for adolescents. Revue Europeene de Psychologie Appliquee. Vol 64, hlm 161-168

[43] Lemos, Igor Lins., Adriana Cardoso., Everton Botelho Sougey. (2016). Validity and realibility assessment of the brazilian version of the game addiction scale (GAS). Comprehensive Psychiatry. Vol 67, hlm 19-25

[44] Mulyana, Deddy., Solatun. (2008). Metode Penelitian Kualitatif. Contoh-contoh penelitian kualitatif dengan Pendekatan Praktis. Bandung : Remaja Rosdakarya

[45] Mulyana, Deddy., Solatun. (2008). Metode Penelitian Kualitatif. Contoh-contoh penelitian kualitatif dengan Pendekatan Praktis. Bandung : Remaja Rosdakarya

[46] (Charlton 2002; Charlton and Danforth 2007)

[47] Granic,

[48] (Grusser, 2007; Sammis, 2008; Oggins, 2010; Dhiraj, 2013; Kowert, 2015; Hussain, 2015; Chen, 2015);

[49] (Park, 2007; Langley, 2010; Kesser, 2012; McBroom, 2013; Sul, 2015; Toker, 2015; Lotton, 2015);

[50] (Ream, 2011; Weng, 2012; Hyun, 2010; Han, 2012; Shiue, 2015); 
[51] (Cheung\&Wong, 2011; Jap, 2013; Lee, 2013; Petry, 2013; Gaetan, 2014; Lemos, 2016).

[52] Ayinla A. S Adekunle B.K, "An overview and Application of Discriminant Analysis in Data " Journal of Mathematics (IOSR-JM), 12-15 (2015).

[53] Gen, M., dan Cheng, R., 2000. Genetic Algorithms and Engineering Optimization.Canada : John Wiley \& Son Inc.

[54] Seputra, Yulius Eka Agung, "Pintar Pemrograman C\#", Face Recognition and Genetic Algoritm, Mediakom, 2013 